\title{
Porphyrobacter donghaensis sp. nov., isolated from sea water of the East Sea in Korea
}

Correspondence

Jung-Hoon Yoon

jhyoon@kribb.re.kr
The genus Porphyrobacter was proposed by Fuerst et al. (1993) with a single species, Porphyrobacter neustonensis. Phylogeny based on 16S rRNA gene sequences has shown that the genus Porphyrobacter belongs to the $\alpha$-subclass of the Proteobacteria (Anzai et al., 2000; Hiraishi et al., 2002; Rainey et al., 2003). Porphyrobacter species are red or orange in colour and synthesize bacteriochlorophyll a (Fuerst et al., 1993; Hanada et al., 1997; Hiraishi et al., 2002; Rainey et al., 2003). At present, the genus Porphyrobacter comprises four species with validly published names: $P$. neustonensis (Fuerst et al., 1993), Porphyrobacter tepidarius (Hanada et al., 1997), Porphyrobacter sanguineus (Hiraishi et al., 2002) and Porphyrobacter cryptus (Rainey et al., 2003). In this study, we report on the detailed taxonomic characterization of two slightly halophilic, reddish-orange-pigmented, Porphyrobacter-like bacterial strains, SW- $132^{\mathrm{T}}$ and SW-158, which were isolated from sea water of the East Sea in Korea.

Strains SW $-132^{\mathrm{T}}$ and SW-158 were isolated by the usual dilution plating technique on marine agar 2216 (MA; Difco)

Published online ahead of print on 17 September 2004 as DOI 10.1099/ijs.0.63226-0.

The GenBank/EMBL/DDBJ accession numbers for the 16S rRNA gene sequences of strains SW-132 ${ }^{\top}$ and SW-158 are AY559428 and AY559429, respectively. at $30^{\circ} \mathrm{C}$. Cell morphology was examined by light microscopy (Nikon E600) and transmission electron microscopy. The presence of flagella was investigated using transmission electron microscopy using cells from exponentially growing cultures. The cells were negatively stained with $1 \%(\mathrm{w} / \mathrm{v})$ phosphotungstic acid and the grids were examined after air-drying with a Philips CM-20 transmission electron microscope. Growth under anaerobic conditions was determined after incubation in an anaerobic chamber on MA and MA supplemented with nitrate that had been prepared anaerobically using nitrogen. Growth in the absence of $\mathrm{NaCl}$ was investigated in trypticase soy broth without $\mathrm{NaCl}$. Growth at various $\mathrm{NaCl}$ concentrations was investigated in marine broth (Difco) or trypticase soy broth (Difco). Growth at various temperatures $\left(4-50{ }^{\circ} \mathrm{C}\right)$ was measured on MA. Catalase and oxidase activities and hydrolysis of casein, starch, Tween 20, Tween 40, Tween 60 and Tween 80 were determined as described by Cowan \& Steel (1965). Hydrolysis of hypoxanthine, tyrosine and xanthine was tested on MA with the substrate concentrations described by Cowan \& Steel (1965). Hydrolysis of aesculin, gelatin and urea and nitrate reduction were studied as described previously (Lanyi, 1987) with the modification that artificial sea water was used for the preparation of media. The artificial sea water contained (per litre of distilled water) $23.6 \mathrm{~g} \mathrm{NaCl}, 0.64 \mathrm{~g} \mathrm{KCl}, 4.53 \mathrm{~g} \mathrm{MgCl}_{2} .6 \mathrm{H}_{2} \mathrm{O}, 5.94 \mathrm{~g}$ $\mathrm{MgSO}_{4} \cdot 7 \mathrm{H}_{2} \mathrm{O}$ and $1.3 \mathrm{~g} \mathrm{CaCl}_{2} \cdot 2 \mathrm{H}_{2} \mathrm{O}$ (Bruns et al., 2001). 
$\mathrm{H}_{2} \mathrm{~S}$ production was tested for as described previously (Bruns et al., 2001). For in vivo pigment-absorption spectrum analysis, two strains were cultivated aerobically in the dark at $30^{\circ} \mathrm{C}$ in Erythromicrobium/Roseococcus medium (Yurkov et al., 1994; DSMZ medium no. 767) with the modification that glucose was used instead of acetate. The cultures were washed twice by centrifugation using a MOPS buffer (MOPS/NaOH, $0 \cdot 01 \mathrm{M} ; \mathrm{KCl}, 0 \cdot 1 \mathrm{M}$; $\left.\mathrm{MgCl}_{2}, 0.001 \mathrm{M} ; \mathrm{pH} 7 \cdot 5\right)$ and disrupted by sonication with a Branson sonifier 450. After removal of cell debris by centrifugation, the absorption spectrum of the supernatant was examined on a Beckman Coulter DU800 spectrophotometer. Susceptibility to antibiotics was detected on agar plates by using antibiotic discs containing chloramphenicol $(100 \mu \mathrm{g})$, penicillin $\mathrm{G}(20 \mathrm{U})$, polymyxin B $(100 \mathrm{U})$ or streptomycin $(50 \mu \mathrm{g})$. Utilization of substrates as sole carbon and energy sources was tested according to the method of Baumann \& Baumann (1981), using supplementation with $2 \%(\mathrm{v} / \mathrm{v})$ Hutner's mineral base (Cohen-Bazire et al., 1957) and $1 \%(\mathrm{v} / \mathrm{v})$ vitamin solution (Staley, 1968).

Cell biomass of strains SW- $132^{\mathrm{T}}$ and SW-158 for respiratory lipoquinone analysis and for DNA extraction was produced in marine broth at $30^{\circ} \mathrm{C}$. Respiratory lipoquinones were analysed as described previously (Komagata \& Suzuki, 1987), using reversed-phase HPLC. Chromosomal DNA was isolated and purified according to the method described previously (Yoon et al., 1996) with the exception that ribonuclease $\mathrm{T} 1$ was used together with ribonuclease A. For fatty acid methyl ester analysis, cell mass of strains SW- $132^{\mathrm{T}}$ and SW-158 was obtained from agar plates after cultivation for 7 days on MA at $30^{\circ} \mathrm{C}$. The fatty acid methyl esters were extracted and prepared according to the standard protocol of the MIDI/Hewlett Packard Microbial Identification System (Sasser, 1990). The DNA G+C content was determined by using the method of Tamaoka \& Komagata (1984) with the modification that DNA was hydrolysed and the resultant nucleotides were analysed by reversed-phase HPLC. The 16S rRNA gene was amplified by using a PCR with two universal primers, as described previously (Yoon et al., 1998). Sequencing of the amplified 16S rRNA gene and phylogenetic analysis were performed as described by Yoon et al. (2003). DNA-DNA hybridization was performed fluorometrically by using the method of Ezaki et al. (1989) with photobiotin-labelled DNA probes and microdilution wells. Hybridization was performed with five replications for each sample. The highest and lowest values obtained in each sample were excluded and the remaining three values were used to calculate similarity values. The DNA relatedness values quoted are the means of the three values.

Strains SW $-132^{\mathrm{T}}$ and SW-158 were similar in terms of most morphological, cultural, physiological and biochemical characteristics. The two strains grew optimally at $30-37^{\circ} \mathrm{C}$ and in the presence of $2 \%(\mathrm{w} / \mathrm{v}) \mathrm{NaCl}$, and they grew without $\mathrm{NaCl}$. Strain $\mathrm{SW}-132^{\mathrm{T}}$ did not grow in the presence of $>6 \% \mathrm{NaCl}$, while strain SW-158 did not grow in the presence of $>7 \% \mathrm{NaCl}$. Sucrose and acetate were utilized by strain SW-132 ${ }^{\mathrm{T}}$, but not by strain SW-158. Both strains produced bacteriochlorophyll $a$ aerobically in the dark. The sonicated cell extracts of the two strains showed absorption maxima at approximately 467, 590, 808 and $867 \mathrm{~nm}$, which indicated the presence of carotenoids and bacteriochlorophyll $a$ (Fig. 1). Acetone/methanol extracts had in vitro maximal absorption peaks at $766-768 \mathrm{~nm}$, confirming the presence of bacteriochlorophyll $a$ (data not shown). Similar in vivo absorption spectra were produced for the other three Porphyrobacter species, with the exception of $P$. sanguineus, which shows a minor difference in absorption spectrum (Fuerst et al., 1993; Hanada et al., 1997; Hiraishi et al., 2002; Rainey et al., 2003). Other morphological, cultural, physiological and biochemical characteristics are shown in Table 1 or are given in the species description (see below). Phenotypic characteristics differentiating strains SW-132 ${ }^{\mathrm{T}}$ and SW-158 from Porphyrobacter species are summarized in Table 1.

The predominant respiratory lipoquinone detected in strains SW-132 ${ }^{\mathrm{T}}$ and SW-158 was Q-10, at peak area ratios of approximately 78-86\%; Q-9 and Q-8 were present as minor components. Strains SW-132 ${ }^{\mathrm{T}}$ and $\mathrm{SW}-158$ showed cellular fatty acid profiles that consisted of straight-chain, unsaturated and hydroxy fatty acids; the major fatty acids were $\mathrm{C}_{18: 1} \omega 7 c$ and $\mathrm{C}_{17: 1} \omega 6 c$ (Table 2). Although similar fatty acid profiles were observed in other Porphyrobacter species, there were differences in the proportions of major fatty acids, which might be caused by different cultivation conditions, e.g. temperature and media used for cultivation (Hiraishi et al., 2002; Rainey et al., 2003). The amounts of unsaturated fatty acid $\mathrm{C}_{18: 1} \omega 7 c$ were lower than those of other Porphyrobacter species, whereas the fatty acid $\mathrm{C}_{17: 1} \omega 6 c$ was a minor component in P. neustonensis and P. tepidarius (Hiraishi et al., 2002; Rainey et al., 2003). The DNA G $+C$ contents of strains SW-132 ${ }^{\mathrm{T}}$ and SW-158 were

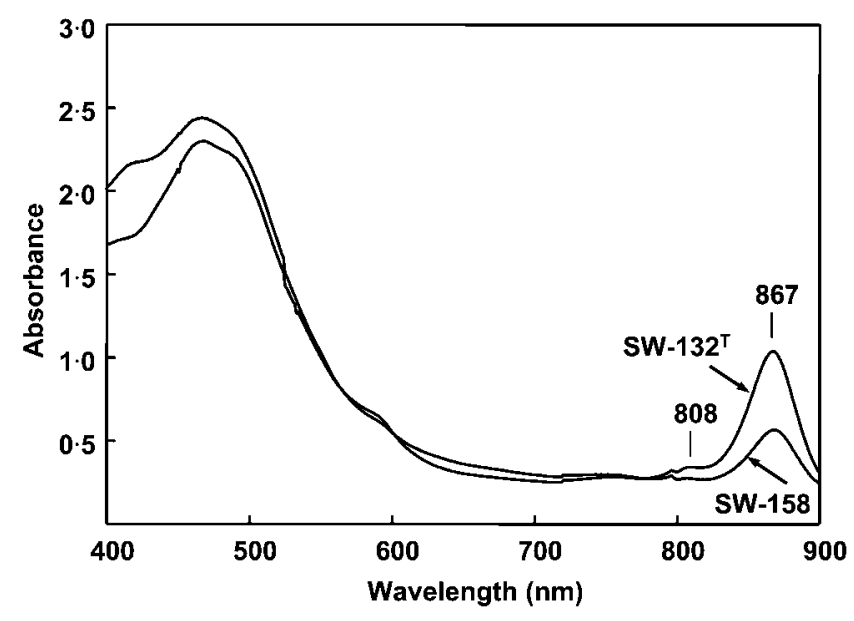

Fig. 1. In vivo absorption spectra of sonicated cell extracts of strains SW-132 ${ }^{\top}$ and SW-158. 
Table 1. Differential phenotypic characteristics of Porphyrobacter species

Taxa: 1, P. neustonensis, data from Fuerst et al. (1993); 2, P. tepidarius, data from Hanada et al. (1997); 3, P. sanguineus, data from Hiraishi et al. (2002); 4, P. cryptus, data from Rainey et al. (2003); 5, P. donghaensis, data from this study. $n$, Number of strains; + , positive reaction; -, negative reaction; $\mathrm{ND}$, not determined; $\mathrm{V}$, variable reaction. Data for the type strain are in parentheses. All species are aerobic, Gram-negative, non-sporulating, positive for the presence of bacteriochlorophyll $a$, positive for the utilization of D-glucose and negative for the utilization of citrate.

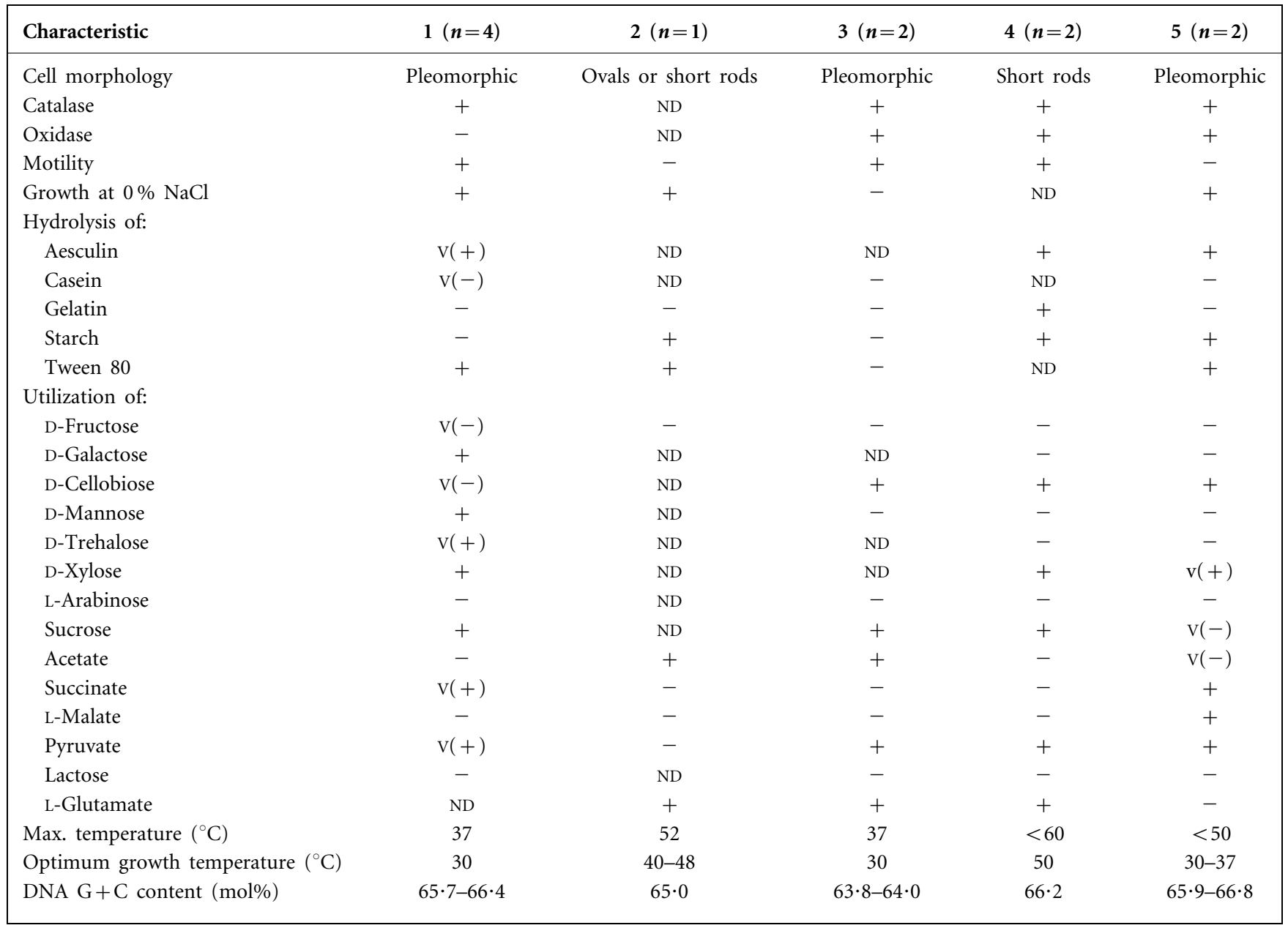

$66 \cdot 8$ and $65.9 \mathrm{~mol} \%$, respectively. The almost-complete $16 \mathrm{~S}$ rRNA gene sequences of strains $\mathrm{SW}-132^{\mathrm{T}}$ and $\mathrm{SW}-158$, comprising $1440 \mathrm{nt}$ (approx. $96 \%$ of the Escherichia coli $16 \mathrm{~S}$ rRNA gene sequence), were determined in this study. There was a $1 \mathrm{nt}$ difference between the 16S rRNA gene sequence of strain SW $-132^{\mathrm{T}}$ and that of strain SW-158. The $16 \mathrm{~S}$ rRNA gene sequence analysis revealed that the two strains have the highest levels of 16S rRNA gene similarity to members of the $\alpha$-Proteobacteria, particularly to the genus Porphyrobacter and to Erythromicrobium ramosum.

Table 2. Cellular fatty acid profiles of strains $S W-132^{\top}$ and $S W-158$

Fatty acids representing $<1.0 \%$ in two strains were omitted. i, iso; ND, not detected.

\begin{tabular}{|c|c|c|c|c|c|c|c|c|c|c|c|c|}
\hline Strain & \multicolumn{12}{|c|}{ Fatty acid composition $(\%)^{*}$} \\
\hline SW-158 & $8 \cdot 2$ & $1 \cdot 4$ & $5 \cdot 4$ & $9 \cdot 4$ & $1 \cdot 2$ & ND & $31 \cdot 5$ & $2 \cdot 7$ & $2 \cdot 4$ & $1 \cdot 6$ & $1 \cdot 3$ & $34 \cdot 2$ \\
\hline
\end{tabular}


Phylogenetic trees based on 16S rRNA gene sequences showed that strains $\mathrm{SW}-132^{\mathrm{T}}$ and $\mathrm{SW}-158$ fall within the radiation of the cluster comprising Porphyrobacter species and Erythromicrobium ramosum (Fig. 2). Strains SW-132 ${ }^{\mathrm{T}}$ and SW-158 exhibited levels of 16S rRNA gene sequence similarity to type strains of Porphyrobacter species and Erythromicrobium ramosum that were between $97 \cdot 8$ and $99 \cdot 0 \%$. The levels of $16 \mathrm{~S}$ rRNA gene sequence similarity between strains SW-132 ${ }^{\mathrm{T}}$ and $\mathrm{SW}-158$ and other species included in the phylogenetic analysis ranged from $97.9 \%$ (Erythrobacter litoralis DSM $8509^{\mathrm{T}}$ ) to $91 \cdot 7 \%$ (Sphingobium yanoikuyae IFO $15102^{\mathrm{T}}$ ). Strains SW-132 ${ }^{\mathrm{T}}$ and SW158 exhibited a mean level of DNA-DNA relatedness of approximately $86 \%$ when their DNAs were used individually as labelled DNA probes for cross-hybridization. Levels of DNA-DNA relatedness between two strains and the type strains of Porphyrobacter species were in the range $9 \cdot 4-20 \cdot 3 \%$.

Phylogenetic analysis based on 16S rRNA gene sequences placed strains SW-132 $2^{\mathrm{T}}$ and SW-158 within a phyletic cluster comprising Porphyrobacter species and Erythromicrobium ramosum (Fig. 2). The relationship between this cluster and the clade that comprised Erythrobacter species was supported by a bootstrap confidence level of $100 \%$ (Fig. 2). The genera Porphyrobacter and Erythromicrobium could not be clearly distinguished since they are not well defined chemotaxonomically and are intermixed phylogenetically (Rainey et al., 2003). The possibility that the genera Porphyrobacter and Erythromicrobium have to be combined into a single genus was proposed by Rainey et al. (2003). This reclassification may be necessary to aid the exact classification of species or strains that are related to the three genera. However, there is still no such proposal, or it may not be appropriate at this time, which leads us to place the two isolates into one of the three genera. Accordingly, since strains SW- $132^{\mathrm{T}}$ and SW-158 exhibit the highest levels of $16 \mathrm{~S}$ rRNA gene sequence similarity to some Porphyrobacter species, it is better to place them in the genus Porphyrobacter before taxonomic criteria regarding the three genera are proposed.
Strains SW-132 ${ }^{\mathrm{T}}$ and SW-158 show very similar phenotypic characteristics. The two isolates are also phylogenetically and genetically similar. In view of these combined data, strains SW- $132^{\mathrm{T}}$ and SW-158 should be considered as members of the same species (Wayne et al., 1987). There are some phenotypic properties differentiating strains SW$132^{\mathrm{T}}$ and SW-158 from Porphyrobacter species, including the ability to utilize some substrates (Table 1). The level of DNA-DNA relatedness, together with differential phenotypic properties and $16 \mathrm{~S}$ rRNA gene sequence similarity data, justify the taxonomic discrimination of SW-132 and SW-158 from all Porphyrobacter species with validly published names (Wayne et al., 1987). Therefore, on the basis of the data presented, strains SW- $132^{\mathrm{T}}$ and SW-158 should be classified in the genus Porphyrobacter as members of a novel species, for which the name Porphyrobacter donghaensis sp. nov. is proposed.

\section{Description of Porphyrobacter donghaensis sp. nov.}

Porphyrobacter donghaensis (dong.ha.en'sis. N.L. masc. adj. donghaensis of Donghae, the Korean name for the East Sea in Korea from which the strains were isolated).

Cells are pleomorphic: cocci, ovals or rods $(0 \cdot 6-0 \cdot 8 \times 0 \cdot 9$ $2.5 \mu \mathrm{m})$ are present. Colonies on MA are smooth, circular, convex, reddish-orange in colour and $0.5-0.8 \mathrm{~mm}$ in diameter after 7 days incubation at $30^{\circ} \mathrm{C}$. Growth occurs at 10 and $45^{\circ} \mathrm{C}$ but not at 4 or $50^{\circ} \mathrm{C}$. The optimal pH for growth is $\mathrm{pH} 7 \cdot 0-8 \cdot 0$; growth is observed at $\mathrm{pH} 5 \cdot 0$ but not at $\mathrm{pH} 4 \cdot 5$. Optimal growth occurs in the presence of $2 \%(\mathrm{w} / \mathrm{v}) \mathrm{NaCl}$; growth does not occur in the presence of $>7 \% \mathrm{NaCl}$. Growth does not occur under anaerobic conditions on MA and on MA with nitrate. Bacteriochlorophyll $a$ and carotenoids are present. Urease-negative. Tween 20, Tween 40, Tween 60 and tyrosine are hydrolysed. Hypoxanthine and xanthine are not hydrolysed. $\mathrm{H}_{2} \mathrm{~S}$ is not produced. Sensitive to chloramphenicol $(100 \mu \mathrm{g})$ and penicillin $\mathrm{G}(20 \mathrm{U})$. Resistant to polymyxin B (100 U) and streptomycin $(50 \mu \mathrm{g})$. Maltose is utilized. Benzoate and

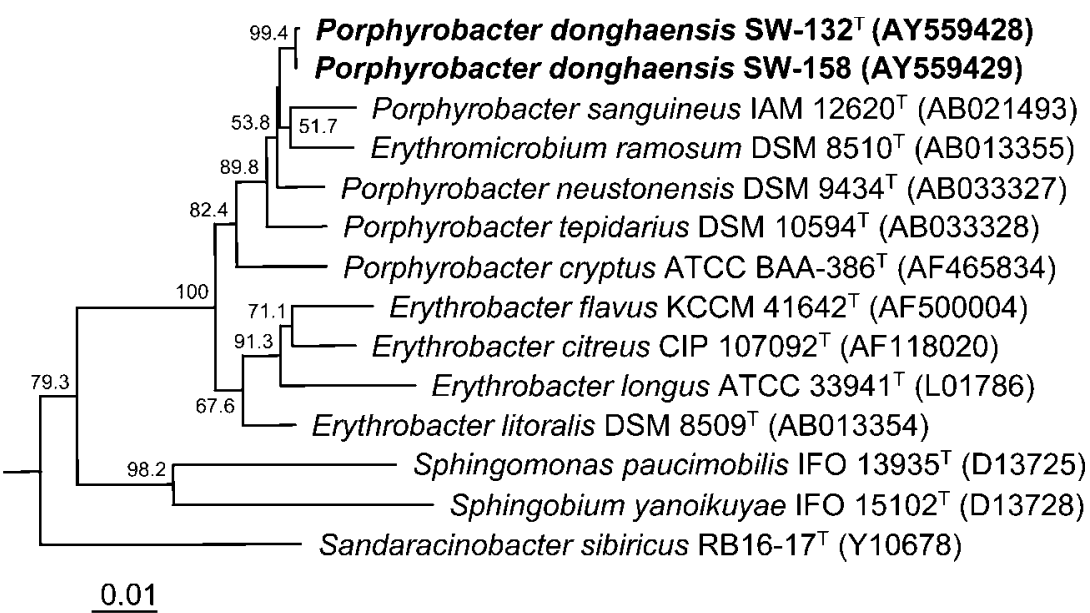

Fig. 2. Neighbour-joining tree, based on 16S rRNA gene sequence data, showing the phylogenetic positions of strains SW$132^{\top}$ and SW-158 and representatives of some related taxa. Bootstrap values (1000 replications) are shown as percentages at each node only if they are $50 \%$ or greater. Bar, 0.01 substitution per nucleotide position. Rhodospirillum rubrum ATCC $11170^{\top}$ was used as the outgroup. 
formate are not utilized. The predominant respiratory lipoquinone is Q-10. The major fatty acids are $\mathrm{C}_{18: 1} \omega 7 c$ and $\mathrm{C}_{17: 1} \omega 6 c$. The DNA G $+\mathrm{C}$ content is $65 \cdot 9-66 \cdot 8 \mathrm{~mol} \%$ ( $66.8 \mathrm{~mol} \%$ for the type strain) (determined by HPLC). Other phenotypic characteristics are given in Tables 1 and 2.

The type strain, SW $-132^{\mathrm{T}} \quad\left(=\mathrm{KCTC} \quad 12229^{\mathrm{T}}=\mathrm{DSM}\right.$ $16220^{\mathrm{T}}$ ), and reference strain SW-158 (= KCTC 12230) were isolated from sea water from the East Sea in Korea.

\section{Acknowledgements}

This work was supported by the 21C Frontier Program of Microbial Genomics and Applications (grant MG02-0401-001-1-0-0) from the Ministry of Science and Technology (MOST) of the Republic of Korea.

\section{References}

Anzai, Y., Kim, H., Park, J.-Y., Wakabayashi, H. \& Oyaizu, H. (2000). Phylogenetic affiliation of the pseudomonads based on 16S rRNA sequence. Int J Syst Evol Microbiol 50, 1563-1589.

Baumann, P. \& Baumann, L. (1981). The marine Gram-negative eubacteria: genera Photobacterium, Beneckea, Alteromonas, Pseudomonas, and Alcaligenes. In The Prokaryotes, pp. 1302-1331. Edited by M. P. Starr, H. Stolp, H. G. Trüper, A. Balows \& H. G. Schlegel. Berlin: Springer.

Bruns, A., Rohde, M. \& Berthe-Corti, L. (2001). Muricauda ruestringensis gen. nov., sp. nov., a facultatively anaerobic, appendaged bacterium from German North Sea intertidal sediment. Int J Syst Evol Microbiol 51, 1997-2006.

Cohen-Bazire, G., Sistrom, W. R. \& Stanier, R. Y. (1957). Kinetic studies of pigment synthesis by nonsulfur purple bacteria. J Cell Comp Physiol 49, 25-68.

Cowan, S. T. \& Steel, K. J. (1965). Manual for the Identification of Medical Bacteria. London: Cambridge University Press.

Ezaki, T., Hashimoto, Y. \& Yabuuchi, E. (1989). Fluorometric deoxyribonucleic acid-deoxyribonucleic acid hybridization in microdilution wells as an alternative to membrane filter hybridization in which radioisotopes are used to determine genetic relatedness among bacterial strains. Int J Syst Bacteriol 39, 224-229.

Fuerst, J. A., Hawkins, J. A., Holmes, A., Sly, L. I., Moore, C. J. \& Stackebrandt, E. (1993). Porphyrobacter neustonensis gen. nov., sp. nov., an aerobic bacteriochlorophyll-synthesizing budding bacterium from fresh water. Int J Syst Bacteriol 43, 125-134.
Hanada, S., Kawase, Y., Hiraishi, A., Takaichi, S., Matsuura, K., Shimada, K. \& Nagashima, K. V. P. (1997). Porphyrobacter tepidarius sp. nov., a moderately thermophilic aerobic photosynthetic bacterium isolated from a hot spring. Int J Syst Bacteriol 47, 408-413.

Hiraishi, A., Yonemitsu, Y., Matsushita, M., Shin, Y. K., Kuraishi, H. \& Kawahara, K. (2002). Characterization of Porphyrobacter sanguineus sp. nov., an aerobic bacteriochlorophyll-containing bacterium capable of degrading biphenyl and dibenzofuran. Arch Microbiol 178, 45-52.

Komagata, K. \& Suzuki, K. (1987). Lipids and cell-wall analysis in bacterial systematics. Methods Microbiol 19, 161-203.

Lanyi, B. (1987). Classical and rapid identification methods for medically important bacteria. Methods Microbiol 19, 1-67.

Rainey, F. A., Silva, J., Nobre, M. F., Silva, M. T. \& da Costa, M. S. (2003). Porphyrobacter cryptus sp. nov., a novel slightly thermophilic, aerobic, bacteriochlorophyll a-containing species. Int J Syst Evol Microbiol 53, 35-41.

Sasser, M. (1990). Identification of Bacteria by Gas Chromatography of Cellular Fatty Acids. Newark: MIDI.

Staley, J. T. (1968). Prosthecomicrobium and Ancalomicrobium: new prosthecate freshwater bacteria. J Bacteriol 95, 1921-1942.

Tamaoka, J. \& Komagata, K. (1984). Determination of DNA base composition by reverse-phase high-performance liquid chromatography. FEMS Microbiol Lett 25, 125-128.

Wayne, L. G., Brenner, D. J., Colwell, R. R. \& 9 other authors (1987). International Committee on Systematic Bacteriology. Report of the ad hoc committee on reconciliation of approaches to bacterial systematics. Int J Syst Bacteriol 37, 463-464.

Yoon, J.-H., Kim, H., Kim, S.-B., Kim, H.-J., Kim, W. Y., Lee, S. T., Goodfellow, M. \& Park, Y.-H. (1996). Identification of Saccharomonospora strains by the use of genomic DNA fragments and rRNA gene probes. Int J Syst Bacteriol 46, 502-505.

Yoon, J.-H., Lee, S. T. \& Park, Y.-H. (1998). Inter- and intraspecific phylogenetic analysis of the genus Nocardioides and related taxa based on 16S rDNA sequences. Int J Syst Bacteriol 48, 187-194.

Yoon, J.-H., Kim, H., Kim, I.-G., Kang, K. H. \& Park, Y.-H. (2003). Erythrobacter flavus sp. nov., a slight halophile from the East Sea in Korea. Int J Syst Evol Microbiol 53, 1169-1174.

Yurkov, V., Stackebrandt, E., Holmes, A. \& 7 other authors (1994). Phylogenetic positions of novel aerobic, bacteriochlorophyll a-containing bacteria and description of Roseococcus thiosulfatophilus gen. nov., sp. nov., Erythromicrobium ramosum gen. nov., sp. nov., and Erythrobacter litoralis sp. nov. Int J Syst Bacteriol 44, 427-434. 